\title{
Techno-economic analysis and climate change impacts of sugarcane biorefineries considering different time horizons
}

\author{
Tassia L. Junqueira ${ }^{1 *}$, Mateus F. Chagas ${ }^{1,2}$, Vera L. R. Gouveia' ${ }^{1}$, Mylene C. A. F. Rezende ${ }^{1}$, Marcos D. B. Watanabe \\ Charles D. F. Jesus ${ }^{1}$, Otavio Cavalett ${ }^{1}$, Artur Y. Milanez ${ }^{3}$ and Antonio Bonomi ${ }^{1,2}$
}

\begin{abstract}
Background: Ethanol production from lignocellulosic feedstocks (also known as 2nd generation or $2 \mathrm{G}$ ethanol process) presents a great potential for reducing both ethanol production costs and climate change impacts since agricultural residues and dedicated energy crops are used as feedstock. This study aimed at the quantification of the economic and environmental impacts considering the current and future scenarios of sugarcane biorefineries taking into account not only the improvements of the industrial process but also of biomass production systems. Technology assumptions and scenarios setup were supported by main companies and stakeholders, involved in the lignocellulosic ethanol production chain from Brazil and abroad. For instance, scenarios considered higher efficiencies and lower residence times for pretreatment, enzymatic hydrolysis, and fermentation (including pentoses fermentation); higher sugarcane yields; and introduction of energy cane (a high fiber variety of cane).
\end{abstract}

Results: Ethanol production costs were estimated for different time horizons. In the short term, $2 \mathrm{G}$ ethanol presents higher costs compared to 1st generation ( $1 \mathrm{G}$ ) ethanol. However, in the long term, $2 \mathrm{G}$ ethanol is more competitive, presenting remarkable lower production cost than $1 \mathrm{G}$ ethanol, even considering some uncertainties regarding technology and market aspects. In addition, environmental assessment showed that both $1 \mathrm{G}$ (in the medium and long term) and $2 \mathrm{G}$ ethanol can reduce climate change impacts by more than $80 \%$ when compared to gasoline.

Conclusions: This work showed the great potential of $2 \mathrm{G}$ ethanol production in terms of economic and environmental aspects. These results can support new research programs and public policies designed to stimulate both production and consumption of $2 \mathrm{G}$ ethanol in Brazil, accelerating the path along the learning curve. Some examples of mechanisms include: incentives to the establishment of local equipment and enzyme suppliers; and specific funding programs for the development and use of energy cane.

Keywords: Ethanol, Sugarcane, Energy cane, Production costs, Climate change

\section{Background}

Replacing fossil fuels by renewable alternatives to reduce dependence on fossil resources and greenhouse gas (GHG) emissions has received special attention worldwide in the last decades. In Brazil, energy consumption in the transportation sector has increased by $65 \%$ in

\footnotetext{
${ }^{*}$ Correspondence: tassia.junqueira@bioetanol.org.br

1 Laboratório Nacional de Ciência e Tecnologia do Bioetanol (CTBE), Centro Nacional de Pesquisa em Energia e Materiais (CNPEM), Caixa Postal 6192, Campinas, SP CEP 13083-970, Brazil

Full list of author information is available at the end of the article
}

the past decade, reaching 86.3 million metric tons of oil equivalent (Mtoe) in 2014, with gasoline and ethanol representing 30 and $15 \%$ of this total, respectively [1]. In the Brazilian transportation sector, hydrous ethanol is used in the flex-fuel vehicles and anhydrous ethanol is mixed to the gasoline $(18-27.5 \% \mathrm{v} / \mathrm{v})$ for use in the gasolinepowered vehicles [2].

Ethanol is conventionally produced through first-generation (1G) process, based on the conversion of extractable sugars and starch (mostly from sugarcane and corn, respectively). The $1 \mathrm{G}$ ethanol production from sugarcane 
in Brazil is a consolidated large-scale process. This experience is based on a 40-year experience motivated by the creation of PROALCOOL program in the 1970s. The learning curve of $1 \mathrm{G}$ sugarcane ethanol has shown that significant reductions in production cost were achieved over the years, due to the gains in agricultural and industrial yields and to the increase in the scale of production $[3,4]$.

Ethanol can also be produced through second-generation (2G) process using lignocellulosic materials, such as agricultural residues and dedicated energy crops, as feedstock [5-7]. In Brazil, parts of sugarcane lignocellulosic fractions (bagasse and straw) are identified as main feedstocks for $2 \mathrm{G}$ ethanol production [8], taking advantage of the possible industrial $1 \mathrm{G}$ and $2 \mathrm{G}$ integration by sharing infrastructure and increasing potential for energy optimization, among other benefits $[9,10]$.

Even though $2 \mathrm{G}$ ethanol has reached commercial scale with a few plants installed worldwide, including two commercial plants in Brazil that recently started operation $(2014 / 2015)$, this process is still at the beginning of its technological learning curve [11]. Some studies suggest that production cost of $2 \mathrm{G}$ ethanol is still higher than that of $1 \mathrm{G}$ ethanol, due to the higher capital expenditures and operating expenses $[9,12,13]$. Therefore, at this initial stage it is likely that $2 \mathrm{G}$ ethanol will depend on governmental polices and incentives, such as the RFS (Renewable Fuel Standard) in USA [14, 15]. In Brazil, special credit lines for research and development (R\&D) on biomass conversion and for the construction of $2 \mathrm{G}$ ethanol plants were available within the PAISS initiative-joint plan for supporting industrial technological innovation in the sugar-based energy and chemical sectors [16]. While in Brazil most incentives focus on providing funds for R\&D and plant implementation, in other countries, especially in the USA, mechanisms to increase the consumption of $2 \mathrm{G}$ ethanol have been practiced [17].

Techno-economic and environmental assessments have been increasingly used to compare different process configurations for $2 \mathrm{G}$ ethanol production, including combination of pretreatments, variation in enzyme dosages, alternative pentoses utilization, among others [18-20]. Evaluation of sugarcane biorefineries considering target yields of $2 \mathrm{G}$ process showed that an integrated $1 \mathrm{G} 2 \mathrm{G}$ plant can be more profitable than a $1 \mathrm{G}$ plant. Also, utilization of pentoses for ethanol production instead of biodigestion is an important driver for the reduction in production costs $[9,21]$. In terms of environmental impacts, Dias et al. [9] showed that high consumption of chemicals in $2 \mathrm{G}$ process, e.g., in the delignification step, can increase climate change impacts compared to $1 G$ ethanol production process.
Some other studies have evaluated expected advances for integrated 1G2G process in Brazil. Silva et al. [22] carried out a life cycle assessment (LCA) of prospective $1 \mathrm{G}$ and 1G2G scenarios (2020-2030) compared to current ethanol production. Jonker et al. [23] evaluated economic results for different biomass crops and industrial technologies considering 2010 and 2030 scenarios. This study showed that ethanol production costs decrease over time due to increase of industrial scale, biomass yield, and industrial efficiency. Wang et al. [13] performed an economic and GHG emission analysis of sugarcane ethanol production considering the projections for 2010-2020 period, with most parameters based on literature. Results indicated that the combined production cost of $1 \mathrm{G}$ and $2 \mathrm{G}$ ethanol can be significantly reduced over time, being comparable to $1 \mathrm{G}$ cost in 2020. A similar trend was observed for climate change impacts.

However, these studies projecting $2 \mathrm{G}$ technologies were based on literature and without a set of scenarios representing a continuous learning curve for both $1 \mathrm{G}$ and 2G ethanol production processes. In this work, production costs and climate change impacts for $1 G$ and $2 \mathrm{G}$ ethanol were quantified considering the technological and economic projections between 2015 and 2030 . The projections considered improvements not only of industrial processes but also of biomass production systems (e.g., inclusion of energy cane as feedstock). It is important to highlight that these scenarios were set up and discussed with specialists from main companies and stakeholders, from Brazil and abroad, involved in the lignocellulosic ethanol production chain. The objective was to forecast the technological learning curve for both $1 \mathrm{G}$ and $2 \mathrm{G}$ ethanol production processes, including both biomass production and industrial conversion, and to quantify economic and environmental impacts of present and future technologies for ethanol production. These results can support the proposition of research programs and public policies to stimulate both production and consumption of $2 \mathrm{G}$ ethanol in Brazil.

\section{Methods}

The Virtual Sugarcane Biorefinery (VSB), developed at the Brazilian Bioethanol Science and Technology Laboratory (CTBE), was employed to perform the technoeconomic and environmental assessment of sugarcane biorefineries. The VSB is a computational framework that allows simulation and evaluation of the entire sugarcane chain and other biomasses (from biomass production to final products use) considering the three pillars of sustainability: economic, environmental, and social [24]. In this work, comparison between $1 \mathrm{G}$ plants and integrated $1 G$ and $2 G(1 G 2 G)$ ethanol production units was carried 
out, considering three time horizons: short (2016-2020), medium (2021-2025), and long (2026-2030) terms.

\section{Scenarios definition}

Unlike most industrial facilities, sugarcane biorefineries operate only about 6-8 months per year, since it is limited by the sugarcane harvesting period and, in some areas, by the raining season. As a result, costs related to investment in equipment have significant contribution towards ethanol production cost. Therefore, it is important to take into account strategies to extend operational period in the future of these biorefineries. In this context, energy cane, a sugarcane variety with higher fiber content, is seen as a promising alternative not only because of its high biomass yields but also due to its potential to extend both $1 \mathrm{G}$ and $2 \mathrm{G}$ ethanol production and electricity generation periods.

Scenarios definition considered improvements of sugarcane and energy cane production systems, industrial conversion (both $1 \mathrm{G}$ and $2 \mathrm{G}$ processes), and market perspectives (enzyme cost and investment in equipment) according to the three defined time horizons. As mentioned before, these assumptions and scenarios setup were supported by main companies, stakeholders, and specialists from Brazil and abroad who were involved in the lignocellulosic ethanol production chain.

For $1 \mathrm{G}$ process, a base case was selected as the benchmark to represent the "average" existing autonomous distilleries in Brazil. It is an industrial plant processing 2 million metric tons of sugarcane per year, producing only ethanol as output. Due to the energy-intensive process and inefficient low-pressure boilers, this plant does not export electricity to the grid but is self-sufficient in energy terms. The other scenarios considered a modern autonomous distillery processing 4 million metric tons of sugarcane per year, recovering straw from the fields and, in the medium term onwards, using energy cane as additional feedstock. In this configuration, thermal integration and high-pressure systems for cogeneration of heat and power (CHP) allow not only being self-sufficient in energy terms but also export surplus electricity to the grid.

The configuration of $2 \mathrm{G}$ process was based on steam explosion pretreatment, pentoses (C5 sugars) liquor separation, enzymatic hydrolysis, fermentation of hexoses (C6 sugars) along with 1G juice. Fermentation of pentoses is carried out separately from C6 and $1 \mathrm{G}$ juice. After fermentation, both alcoholic streams are sent to a series of distillation columns and dehydration processes where anhydrous ethanol (99.6 wt\%) is obtained. Ligninrich residual solids from enzymatic hydrolysis are burnt in the CHP as supplementary fuel. Figure 1 shows a representation of the integrated $1 \mathrm{G} 2 \mathrm{G}$ process and Table 1 summarizes the main assumptions for the evaluated scenarios. Detailed information about biomass composition and production system (productivities, mechanization level, others) as well as industrial process (e.g., operational conditions and yields) according to the technology levels and timeframes are presented in the Additional file 1.

\section{Techno-economic and climate change assessment}

The biomass production system was evaluated using the CanaSoft model, an in-house model that integrates and quantifies inputs and outputs in the biomass production stages (from preplanting operations to harvesting and transportation) within the VSB.

Mass and energy balances for each scenario were carried out using Aspen Plus ${ }^{\circledR}$ process simulation environment. These balances provided information for the estimation of operational costs and investments as well as for economic and environmental assessments.

Investments were based on VSB's databank and methodology. In this approach, flows calculated through process simulation are used to estimate equipment capacities. In order to represent new engineering solutions and maturity evolution of $2 \mathrm{G}$ and biodigestion processes, reductions in medium- and long-term estimates equal to 10 and $20 \%$, respectively, were considered for investments in these equipment. Economic assessment considered greenfield projects, i.e., new facilities. Main economic assumptions are presented in Table 2.

This study considered a vertically integrated model, i.e., a company controls both the agricultural and industrial production systems. In this sense, the biomass production cost in the agricultural phase, which is an output of the CanaSoft model, will be interpreted as the cost of biomass in the industrial cash flow analysis instead of considering sugarcane market prices [28]. This assumption is important because the management decisions regarding agricultural technologies to be used in the sugarcane field will impact the entire production chain, including the ethanol production costs at the industry.

\section{Cost allocation}

In this paper, the production cost was selected as the main economic result to compare both $1 \mathrm{G}$ and $2 \mathrm{G}$ ethanol competitiveness over time. The decision on production cost rather than other economic parameters, such as internal rate of return and net present value, was made in order to foster policy-making decisions focusing on reducing ethanol production costs.

The production cost is composed by two main components: operating and capital costs. Operating costs are associated with the annual expenses with feedstock, maintenance, labor, chemical substances, among other 


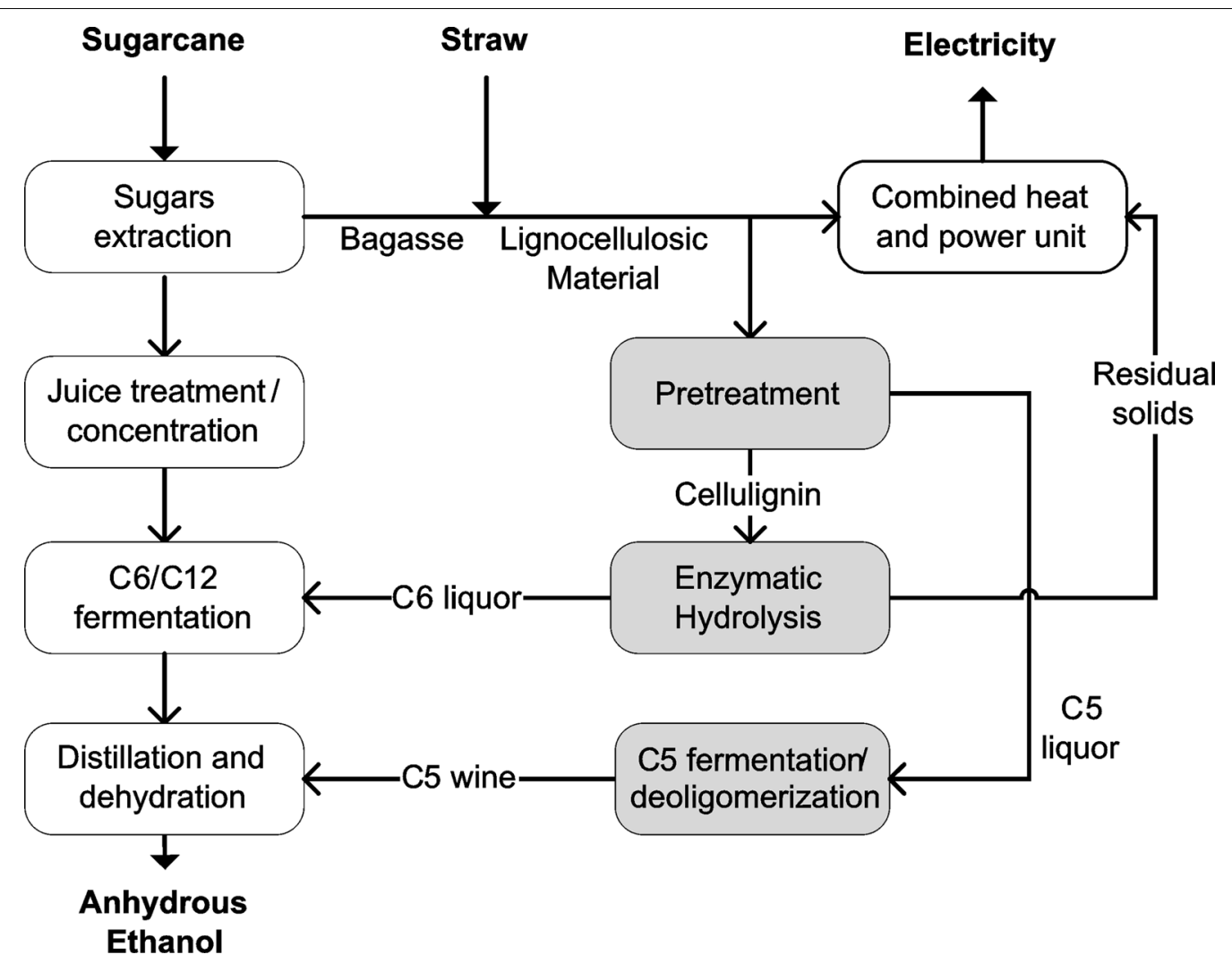

Fig. 1 Block flow diagram for integrated 1G2G process. Process steps usually found in 1G autonomous distilleries (white blocks) and additional steps relative to $2 \mathrm{G}$ process (light gray blocks)

Table 1 Main characteristics of the evaluated scenarios

\begin{tabular}{|c|c|c|c|c|c|c|c|}
\hline Scenarios $^{a}$ & 1G-base & 1G-ST & 1G2G-ST & 1G-MT & 1G2G-MT & 1G-LT & 1G2G-LT \\
\hline Sugarcane processing $\left(10^{6} \mathrm{t} / \text { year }\right)^{\mathrm{b}}$ & 2 & 4 & 4 & 4 & 4 & 4 & 4 \\
\hline Straw recovery $(\%)^{c}$ & - & 50 & 50 & 60 & 60 & 70 & 70 \\
\hline Energy cane processing ( $10^{6} \mathrm{t} /$ year $)$ & - & - & - & $1.72^{\mathrm{d}}$ & & $4.17^{e}$ & \\
\hline $1 \mathrm{G}$ technology level & Base & \multicolumn{6}{|c|}{ Optimized (high-pressure boilers and reduced steam consumption) } \\
\hline $2 \mathrm{G}$ yield $(L / t \mathrm{LCM})^{f}$ & - & - & $\sim 240$ & - & $\sim 295$ & - & $\sim 350$ \\
\hline Vinasse biodigestion efficiency (\%) ${ }^{9}$ & - & - & - & 72 & 72 & 80 & 80 \\
\hline
\end{tabular}

a ST, MT, and LT stand for technologies in the short, medium, and long terms, respectively

b Sugarcane is processed during the sugarcane harvesting season (200 days/year)

c The recovery percentage relates to the amount of straw produced in the field. Baling for longer distances ( $50 \%$ of total area) and integral harvesting for short distances ( $50 \%$ of total area). Even with the increment in the sugarcane straw recovery percentages over time, higher projected biomass yields would allow maintaining the same amount of straw in the field (compared to the short term scenarios)

d Energy cane is processed only in the off-season (130 days), using the idle equipment used for conventional sugarcane during season, after some minor adjustments

e Energy cane is processed all-year round. The facility is designed to process both sugarcane and energy cane during the season (200 days). In the off-season (130 days), all installed capacity is employed to process only energy cane

$\mathrm{f}$ This yield is a result of process simulation based on the assumptions for $2 \mathrm{G}$ process in each time horizon. LCM refers to dry lignocellulosic material pretreated in the $2 \mathrm{G}$ process

g Produced biogas is purified and used to replace diesel limited to $70 \%$ in the agricultural operations and transport. Surplus biogas is burnt in internal combustion engines for electricity production

inputs; whereas the capital cost is calculated based on the annual payment that would be necessary to remunerate the total investment at an assumed $12 \%$ per year interest rate over a 25 -year period. This amount of money 
Table 2 Main financial parameters for economic assessment

\begin{tabular}{|c|c|c|}
\hline Parameter & Value & Reference \\
\hline Minimum acceptable rate of return (per year) & $12 \%$ & Watanabe et al. [25] \\
\hline Project life span (years) & 25 & Watanabe et al. [25] \\
\hline Depreciation rate (linear, 10 years) & $10 \%$ & Watanabe et al. [25] \\
\hline Income taxes & $34 \%$ & Milanez et al. [17] \\
\hline Maintenance (\%Capex) & $3 \%$ & Milanez et al. [17] \\
\hline Month/year of reference for economic parameters & July/2014 & - \\
\hline Exchange rate (R\$/US\$) & 2.30 & Average of July, 2014 \\
\hline Enzyme cost—short term (US\$/L 2G ethanol) & 0.13 & Estimate from suppliers \\
\hline Enzyme cost-medium term (US\$/L 2G ethanol) & 0.08 & Estimate from suppliers \\
\hline Enzyme cost-long term (US\$/L 2G ethanol) & 0.06 & Estimate from suppliers \\
\hline Anhydrous ethanol price (R\$/L) & 1.34 & Moving average (2004-2014) [26] \\
\hline Electricity price (R\$/MWh) & 132.43 & Average from auctions (2005-2013) [27] \\
\hline
\end{tabular}

a July/2014 was chosen based on the date when application of questionnaires and interviews with stakeholders took place

represents the opportunity cost of the investment associated with the decision of building a new plant.

Considering that a biorefinery produces more than one product, an allocation criterion for operating and capital costs was applied. Ethanol production cost was calculated considering the allocation of overall yearly costs (operating and capital costs) between ethanol and electricity based on their participation on revenues. In the integrated 1G2G scenarios, an additional allocation step between $1 G$ and $2 G$ ethanol was performed, based on their participation in the ethanol output, to identify the impacts exclusively related to $2 G$ ethanol [25]. In this case, for a same time horizon, it was considered that $1 \mathrm{G}$ ethanol has the same cost in both $1 \mathrm{G}$ and 1G2G scenarios. Therefore, all the additional costs are allocated to $2 \mathrm{G}$ ethanol.

\section{Climate change impacts using life cycle assessment}

The assessment of climate change impacts was performed through life cycle assessment (LCA) methodology. It is a broadly recognized methodology for estimating the environmental burden associated with a product, process, or activity, by the identification and quantification of energy and materials used and waste released, during its entire life cycle [25]. SimaPro software and the Ecoinvent database v2.2 were employed to obtain the datasets of the main inputs used in the product system evaluated (e.g., production of diesel, fertilizers, pesticides, and other chemicals used as input in the process) [25]. The scenarios were assessed using the climate change impact category from ReCiPe Midpoint H v 1.08 method [29], measured in $\mathrm{g} \mathrm{CO}_{2}$ eq per $\mathrm{MJ}$ of ethanol. Equivalency factors of this category are based on the 100-year timeframe radiative forcing of a given greenhouse gas relative to carbon dioxide from IPCC 2007 report [30]. This impact category was selected because the potential to reduce GHG emissions has been one of the main motivations that drive research and use of renewable energy alternatives. For instance, targets of reductions in GHG emissions for biofuels replacing their fossil counterparts have been defined in the RSF2 regulatory framework [31].

\section{Results and discussion}

\section{Techno-economic assessment}

With expected technical improvements of both biomass production systems and industrial conversion, the biomass production costs and the products' output change over time are shown in Tables 3 and 4, respectively.

Significant production cost reduction in sugarcane stalks and straw is achieved in long term (roundly 45 and $25 \%$, respectively), mainly due to the increase in agricultural yields and use of biomethane as partial diesel replacement for agricultural mechanical operations. Cost increments due to lower density of the transported material when large amounts of straw are recovered and transported within the sugarcane stalks led to a small increase in straw costs for long-term scenarios. Therefore, besides the higher agricultural yields, straw costs are largely dependent on transportation costs. Further reduction in biomass production cost is observed with the introduction of energy cane, which is $25-30 \%$ lower than conventional sugarcane costs considering the same time horizon.

Specific ethanol production (per metric ton of cane) in $1 G$ scenarios reduces over time due to the lower sugar content of energy cane in comparison to conventional sugarcane. In spite of that, the total annual ethanol production increases over time. This is a result of the larger amount of processed biomass, integration of $2 \mathrm{G}$ process and its technological advances. 
Table 3 Amount and cost of biomass processed in each scenario

\begin{tabular}{|c|c|c|c|c|c|c|}
\hline \multirow[t]{2}{*}{ Scenario } & \multicolumn{3}{|c|}{ Biomass processed $\left(10^{6} \mathrm{t} / \text { year }\right)^{\mathrm{a}}$} & \multicolumn{3}{|c|}{ Biomass production cost (US\$/t) ${ }^{a}$} \\
\hline & Sugarcane stalks & Sugarcane straw & Energy cane & Sugarcane stalks & Sugarcane straw & Energy cane \\
\hline 1G-base & 2.00 & - & - & 28.00 & - & - \\
\hline $1 \mathrm{G}-\mathrm{ST}$ & 4.00 & 0.25 & - & 29.11 & 27.09 & - \\
\hline 1G-MT & 4.00 & 0.34 & 1.72 & 20.31 & 20.47 & 14.15 \\
\hline $1 \mathrm{G}-\mathrm{LT}$ & 4.00 & 0.39 & 4.17 & 16.15 & 20.66 & 12.10 \\
\hline 1G2G-ST & 4.00 & 0.25 & - & 29.30 & 27.09 & - \\
\hline 1G2G-MT & 4.00 & 0.34 & 1.72 & 20.73 & 20.47 & 14.33 \\
\hline 1G2G-LT & 4.00 & 0.39 & 4.17 & 16.68 & 20.66 & 12.63 \\
\hline
\end{tabular}

a Amount and cost of sugarcane straw are expressed in dry basis. Values for sugarcane stalks and energy cane are expressed in wet basis

Table 4 Overall ethanol production (1G plus 2G), surplus electricity, and 2G yield for evaluated scenarios

\begin{tabular}{llllll}
\hline Scenario & $\begin{array}{l}\text { Ethanol production } \\
\left(\mathbf{1 0}^{\mathbf{3}} \mathbf{~ m}^{\mathbf{3}} \text { /year) }\right.\end{array}$ & $\begin{array}{l}\text { Surplus electricity } \\
(\mathbf{G W h} / \text { year })\end{array}$ & $\begin{array}{l}\text { Ethanol production } \\
\left(\mathbf{L} / \mathbf{T C}^{\mathbf{a}}\right)\end{array}$ & $\begin{array}{l}\text { Surplus electricity } \\
\left(\mathbf{k W h} / \mathbf{T C}^{\mathbf{a}}\right)\end{array}$ & $\begin{array}{l}\mathbf{2 G} \text { yield } \\
\left(\mathbf{L} / \mathbf{L C M}^{\mathbf{b}}\right)\end{array}$ \\
\hline 1G-base & 170.4 & - & 85.2 & - & - \\
1G-ST & 339.7 & 697.5 & 84.9 & 174.3 & - \\
1G-MT & 438.3 & 1153.7 & 76.6 & 201.5 & - \\
1G-LT & 561.6 & 1769.8 & 68.8 & 216.7 & - \\
1G2G-ST & 433.9 & 274.3 & 108.4 & 68.6 & 237.5 \\
1G2G-MT & 667.4 & 403.2 & 116.6 & 70.4 & 293.0 \\
1G2G-LT & 989.1 & 555.4 & 121.1 & 68.0 & 348.9 \\
\hline
\end{tabular}

a TC refers to metric tons of cane (either sugarcane stalks or energy cane)

b LCM refers to dry lignocellulosic material pretreated in the $2 \mathrm{G}$ process

The $2 \mathrm{G}$ yield for the different time horizons is a result of the assumed set of process parameters (detailed in Additional file 1) included as inputs in the mass and energy balances. In the short term, $237 \mathrm{~L}$ of ethanol is produced per metric ton of dry biomass processed in $2 G$ unit. This figure is consistent with the information released by Raízen, one of Brazil's pioneers in $2 \mathrm{G}$ ethanol production. Raízen claims to obtain $211 \mathrm{~L}$ per metric ton of dry biomass and expects to achieve $289 \mathrm{~L}$ at full capacity operation [12]. The theoretical ethanol yield for sugarcane biomass is estimated at about $422 \mathrm{~L} / \mathrm{t}$ (dry basis) [32], so results for the long-term scenarios ( 350 $\mathrm{L} / \mathrm{t}$ ) seem reasonable for 2030 . The experience with $1 \mathrm{G}$ ethanol in Brazil has shown that economies of scale and technological advances may lead to a remarkable increase in its competitiveness as fuel [4].

Comparing $1 \mathrm{G}$ and 1G2G scenarios, 2G technology allows increasing ethanol production by 28,52 and $76 \%$ in the short, medium, and long terms, respectively. The increase in ethanol production is a result of three main factors: increase in $2 \mathrm{G}$ yield; the introduction of energy cane; and reduction in steam demand (which increases biomass availability for $2 \mathrm{G}$ process) due to higher solid content and sugar concentration in the process steps.
Energy cane presents higher fiber content, being a feedstock more suitable for $2 \mathrm{G}$ ethanol production. At the same time, it presents less readily fermentable sugars, thus the 1G ethanol yield is lower in energy cane in comparison to sugarcane, increasing the differences between $1 \mathrm{G}$ and $1 \mathrm{G} 2 \mathrm{G}$ ethanol production for the same time horizon. For example, in the 1G2G-LT scenario, almost one billion liters of ethanol is produced per year, which is equivalent to an autonomous $1 \mathrm{G}$ plant processing around 12 million metric tons of conventional sugarcane per year. In the 1G2G scenarios, since all surplus lignocellulosic material is diverted to pretreatment, the electricity outputs are about one-third of those achieved in the 1G scenarios, considering the same time horizons.

The investment for each scenario is presented in Table 5 . For comparison purposes, the investments were divided into two sectors: $1 \mathrm{G}+$ interface and $2 \mathrm{G}$. The first sector aggregates the processing areas usually found in the conventional first-generation ethanol plants (such as sugarcane reception, juice extraction, juice treatment, fermentation, distillation, CHP unit), biodigestion unit, administrative infrastructure, engineering, among others. The $2 \mathrm{G}$ sector includes areas specifically related to $2 \mathrm{G}$ processes, such as pretreatment, $\mathrm{C} 5$ fermentation, and 
Table 5 Estimated industrial investment for each scenario

\begin{tabular}{|c|c|c|c|c|c|c|c|}
\hline Capex (US\$ million) & 1G-base & 1G-ST & 1G-MT & 1G-LT & 1G2G-ST & 1G2G-MT & 1G2G-LT \\
\hline $1 G+$ interface areas (subtotal) & 153.3 & 436.4 & 472.8 & 627.6 & 410.2 & 455.6 & 586.4 \\
\hline Administrative infrastructure, engineering, and utilities & 41.6 & 99.3 & 105.8 & 137.7 & 127.1 & 131.4 & 163.7 \\
\hline Sugarcane reception, juice extraction, and evaporation & 33.6 & 60.5 & 63.6 & 79.2 & 63.4 & 67.5 & 82.4 \\
\hline Ethanol production (fermentation, distillation/dehydration) & 37.2 & 83.5 & 80.6 & 97.0 & 103.4 & 114.0 & 154.8 \\
\hline Combined heat and power (steam and electricity) & 40.9 & 193.1 & 211.6 & 300.8 & 116.4 & 124.7 & 160.8 \\
\hline $\begin{array}{l}\text { Biogas production, purification, and use for electricity generation (internal } \\
\text { combustion engines) }\end{array}$ & - & - & 11.1 & 13.0 & - & 18.0 & 24.7 \\
\hline $2 G$ areas(subtotal) & - & - & - & - & 184.9 & 163.4 & 190.1 \\
\hline Pretreatment and C5 liquor separation/evaporation & - & - & - & - & 106.5 & 102.3 & 127.7 \\
\hline C 5 fermentation and yeast propagation & - & - & - & - & 15.7 & 16.5 & 16.9 \\
\hline Enzymatic hydrolysis and C6 liquor separation & - & - & - & - & 62.7 & 44.6 & 45.4 \\
\hline Total & 153.3 & 436.4 & 472.8 & 627.6 & 595.1 & 619.0 & 776.5 \\
\hline
\end{tabular}

enzymatic hydrolysis. The highest investment estimates are observed for the long-term scenarios (1G-LT and 1G2G-LT), due to the higher installed capacities and larger cost-intensive areas, such as the CHP (considering an optimized configuration) in 1G-LT and $2 \mathrm{G}$ plants (in particular, pretreatment and C5 liquor separation) in 1G2GLT. At the same time, the lowest investment is related to 1G-base scenario, which has the lowest plant capacity and base technological level. The 1G+ interface investment in 1 G2G scenarios is lower than those of $1 \mathrm{G}$ scenarios, even with the increase in fermentation and ethanol production areas that are shared between both processes, because the CHP unit capacity is smaller in 1 G2G scenarios due to the use of biomass for $2 \mathrm{G}$ ethanol production.

Operational costs were estimated for each scenario based on the expenses with raw materials, labor, maintenance, enzymes, among others. These costs, added to the capital costs (relative to the investment), are allocated between the biorefinery products to obtain the ethanol production cost, as described in the "Methods" section. Projected ethanol production costs over time are shown in Fig. 2, along with the oil price required to produce gasoline with equivalent cost in energy basis. These estimations consider the share of West Texas intermediate (WTI) crude oil on the US gasoline price breakdown according to the data from the US Energy Information Administration [33]. Figure 3 shows the breakdown of $2 \mathrm{G}$ ethanol production costs for the three integrated 1G2G scenarios.

Ethanol production costs for $1 \mathrm{G}$ scenarios in the short term (1G-Base and 1G-ST) presented similar values. Although the modern configuration (1G-ST) has an extra revenue from electricity (which reduces the fraction of the total costs allocated to ethanol), higher capital costs (mainly related to CHP unit) and additional costs with

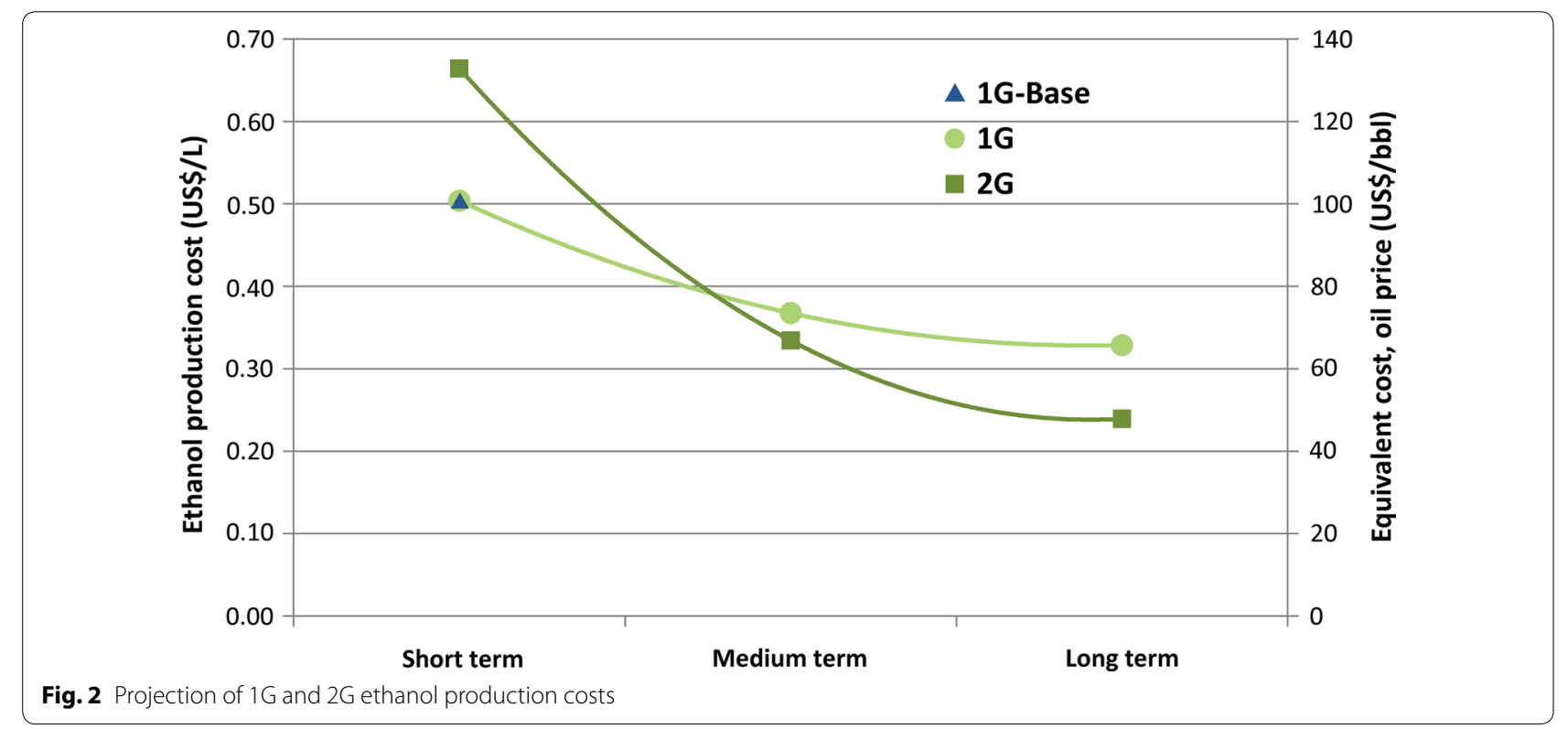




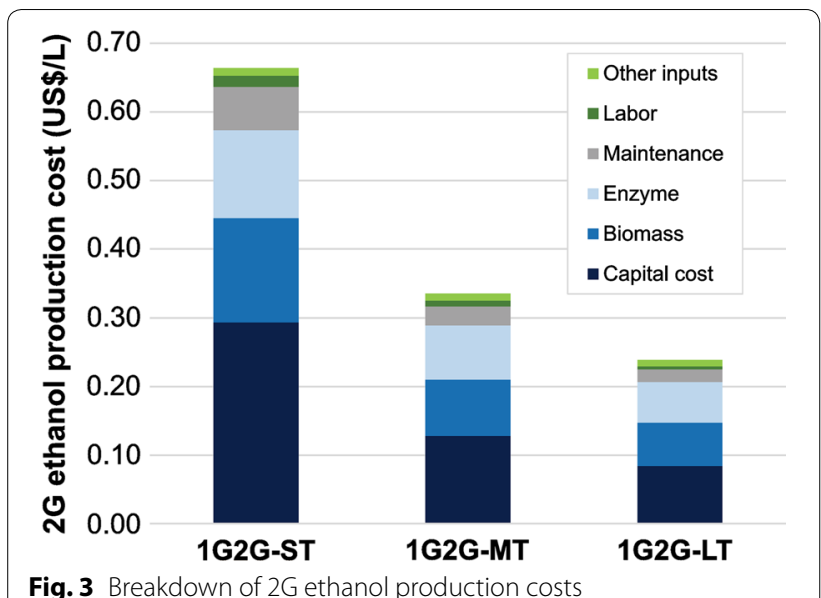

straw recovery result in increased ethanol production cost. 2G ethanol presents higher costs than $1 G$ in the short term mainly due to high capital cost associated with the additional investment and enzyme costs that together represent roughly $65 \%$ of the total $2 \mathrm{G}$ cost. Although both costs are expected to reduce over time, the trend shows that $2 \mathrm{G}$ ethanol cost will be lower in the medium and long terms if the expected technological advances are obtained. For instance, the capital cost, which is the main component of production cost, is significantly reduced due to lower residence times and higher solid contents in the $2 \mathrm{G}$ process. Additionally, reductions in investment estimates in the medium and long terms are anticipated because of the development of local equipment manufacturers, which are assumed to deliver more cost-competitive solutions overtime. Biomass costs also decrease over time as a consequence of projected developments in the agricultural production system, including the introduction of energy cane. Another driver for reduction in $2 \mathrm{G}$ ethanol production costs is the cost of enzyme, which is expected to have lower contribution with the development of more efficient enzymatic cocktails and establishment of local enzyme producers.

As Figs. 2 and 3 depicted, $2 \mathrm{G}$ cost is lower than $1 \mathrm{G}$ from medium to long terms due to the relatively faster decrease of $2 \mathrm{G}$ costs. These results rely on a variety of assumptions. First, the $2 \mathrm{G}$ technology is still in the beginning of its technological learning curve whereas $1 \mathrm{G}$ is a mature technology which has a lower potential for cost decrease in the industrial stage. Biomass cost reductions are still possible (due to new sugarcane varieties and the introduction of energy cane); therefore, $1 G$ ethanol can experience further cost reduction mostly related to advances in the agricultural production systems. Second, the high costs associated with $2 \mathrm{G}$ technology rely on the current choices of industrial routes and equipment design (such as those dedicated to pretreatment area) that may evolve over the years. Considering the potential of reduction in capital, and enzyme and biomass costs with the increase of industrial yields, $2 \mathrm{G}$ technology has higher potential of cost reduction over time.

The comparison of ethanol production costs and the oil price in the international scenario (Fig. 2) indicates that both $1 \mathrm{G}$ and $2 \mathrm{G}$ ethanol are competitive in the short term if oil prices exceed US\$ 100/bbl and US\$ 130/bbl, respectively. In the long term, ethanol competitiveness is achieved for oil prices above US\$ 65/bbl and US\$ 45/ bbl for $1 G$ and $2 \mathrm{G}$ ethanol, respectively. For comparison, although oil price has recently dropped to lower levels, it ranged from US\$ 60/bbl to US\$ 115/bbl between 2010 and 2014 [34].

\section{Sensitivity analysis}

Sensitivity analysis was carried out to evaluate the impact of possible variations on biomass, enzymes, and capital costs in both $1 G$ and $2 \mathrm{G}$ ethanol production costs. In addition, variation in electricity price, which affects the allocation of production costs, was applied to show its influence on the results. Figure 4 presents the projection curve of ethanol production cost including a sensitivity analysis.

Due to the larger investment of integrated 1G2G scenarios, capital cost has a higher impact on $2 \mathrm{G}$ ethanol production cost, especially in the short term, overlapping with $1 \mathrm{G}$ ethanol production cost. On the other hand, biomass influences more $1 \mathrm{G}$ ethanol, since it is the most important component of its production cost. As enzyme affects only $2 \mathrm{G}$ ethanol production cost, a lower impact in the projection curve is observed. Even so, the comparison shows that the uncertainties in enzyme price could approximate $1 \mathrm{G}$ and $2 \mathrm{G}$ ethanol production costs in the medium term.

The impact of electricity price on the ethanol production cost is on allocation. For higher prices, electricity participation in the revenues increases, reducing $1 \mathrm{G}$ ethanol production cost. Similarly, $1 G 2 \mathrm{G}$ ethanol production cost also decreases but by a smaller factor (due to lower electricity output). However, because of the reduction in the $1 \mathrm{G}$ ethanol production cost, $2 \mathrm{G}$ ethanol production cost increases. In this case, a variation of $50 \%$ was assumed due to the high uncertainty and variability of electricity prices in Brazil. The impact on hydropower availability affects reference prices of other renewable sources in the electricity market-such as solar, wind, and biomass - mainly due to the increasing demand of high cost electricity dispatched to the grid (from oil and natural gas-fired power plants).

It is worth highlighting that the exchange rate is also an important variable, which impacts $2 \mathrm{G}$ ethanol 


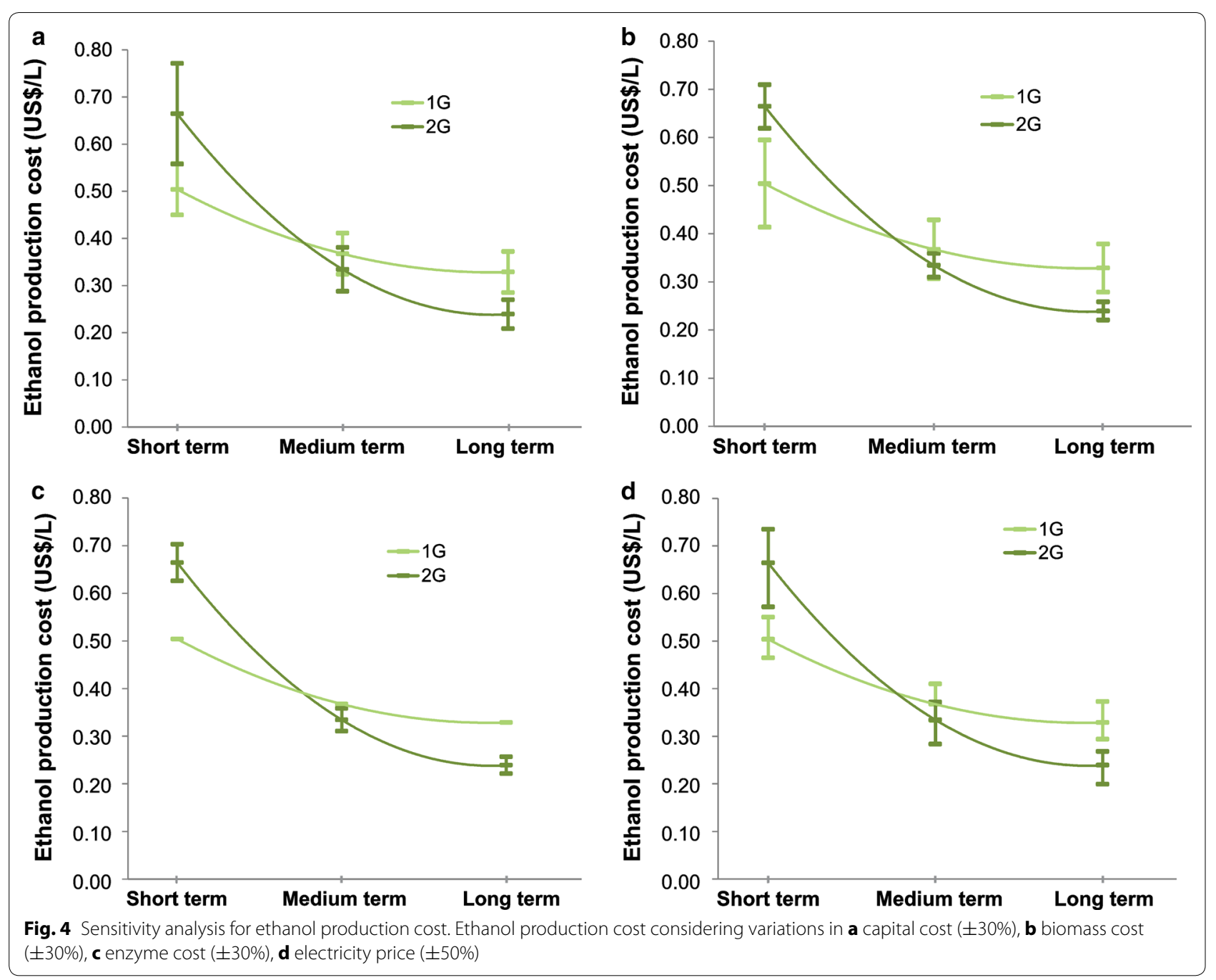

production costs in the Brazilian currency. Considering that a significant share of imported 2G equipment (pretreatment reactor, for instance) is estimated in US dollars and that enzymes are reliant on prices set by foreign companies, a high exchange rate volatility may increase uncertainties to the $2 \mathrm{G}$ production costs in the Brazilian market, especially in the short term. However, as much as the $2 \mathrm{G}$ ethanol internal market becomes more competitive and mature over time, it is expected that this effect may decrease due to a possible expansion of local $2 \mathrm{G}$ equipment and enzyme manufacturers.

\section{Climate change impacts}

Environmental impacts for electricity, 1G ethanol, and 2G ethanol were allocated using the same criteria employed in the economic assessment; thus, impacts are proportional to the participation of each product on revenues. Figure 5 presents climate change impacts of ethanol for the evaluated scenarios, considering a cradle-to-gate analysis. At this point, for comparison purposes, impacts related to biofuel distribution and use were not included since there is no expected difference in these life cycle steps for the considered scenarios.

The highest environmental impacts (around $24 \mathrm{gCO}_{2}$ eq/MJ) are related to the $1 \mathrm{G}$-base scenario, which commercializes only ethanol. In the 1G-ST, part of the impacts is allocated to electricity production, therefore reducing ethanol impacts. Increase in biomass yield and use of biomethane as diesel replacement play an important role in the reduction in GHG emissions, dropping it below $14 \mathrm{gCO}_{2} \mathrm{eq} / \mathrm{MJ}$ in the $1 \mathrm{G}-\mathrm{LT}$ scenario. Due to higher ethanol yields (i.e., more ethanol is produced with the same biomass), the climate change impacts for $2 \mathrm{G}$ ethanol production were lower than that of $1 \mathrm{G}$ scenarios for all time horizons. The expected advances on $2 \mathrm{G}$ technology led to a substantial climate change impact mitigation, resulting in values as low as $7.5 \mathrm{gCO}_{2} \mathrm{eq} / \mathrm{MJ}$ in the 1G2G-LT scenario. 


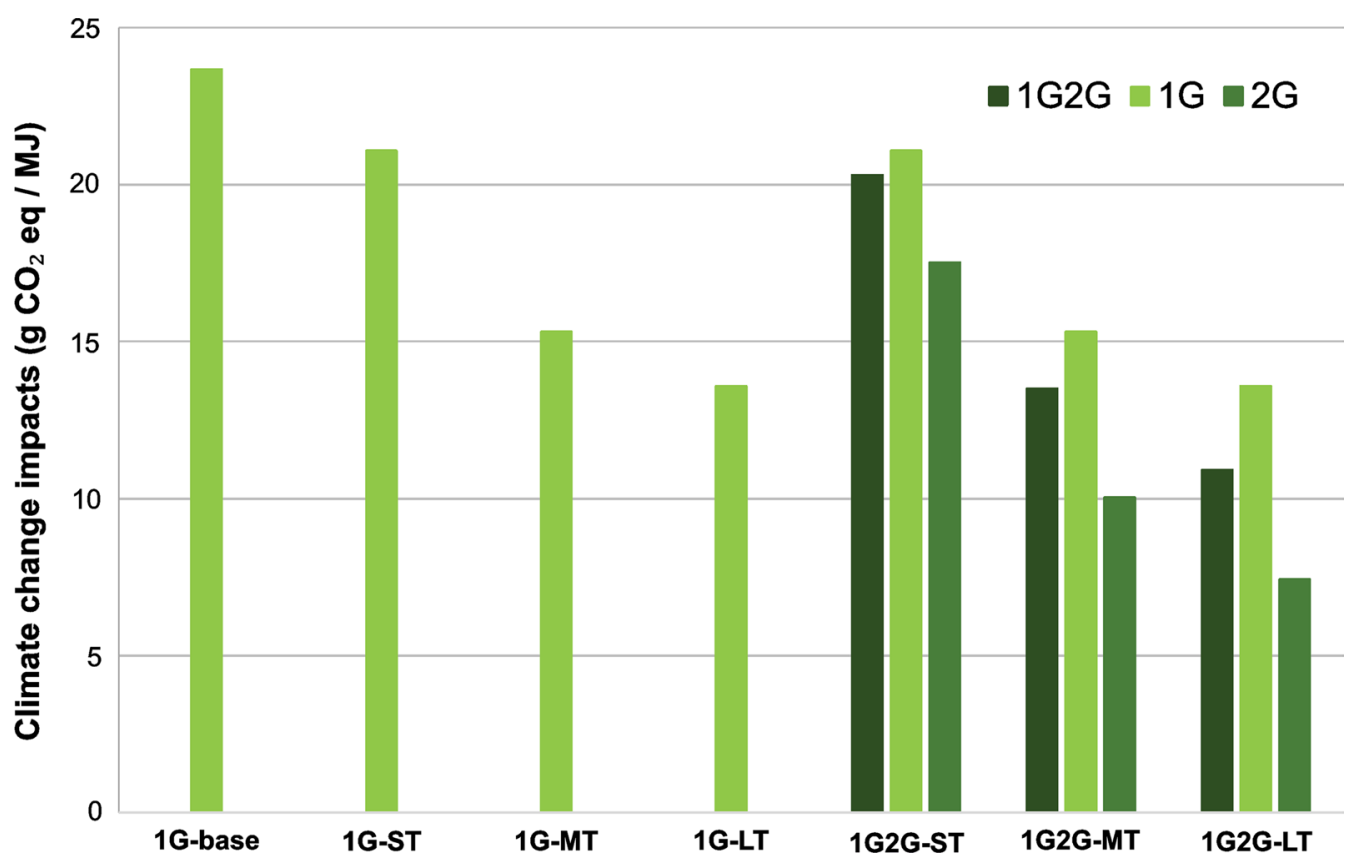

Fig. 5 Climate change impacts per unit of energy of ethanol produced in the considered scenarios

To compare ethanol GHG emissions with those from gasoline, the entire life cycle needs to be considered (cradle-to-grave analysis). In this sense, the emissions from ethanol distribution and use $\left(1.03 \mathrm{~g} \mathrm{CO}_{2}\right.$ eq/MJ, for all the evaluated scenarios) were added to ethanol cradleto-gate results from Fig. 5. The LCA was applied to both ethanol and gasoline under same conditions, methods, and databases, making this comparison reasonable. Considering that the production and use of gasoline in Brazil emits $87.4 \mathrm{~g} \mathrm{CO}_{2}$ eq/MJ, $1 \mathrm{G}$ ethanol in medium and long terms and $2 \mathrm{G}$ ethanol present climate change impact reduction by over $80 \%$ in comparison to gasoline. This result is in line with other important studies for Brazilian sugarcane ethanol (not including land use change emissions or ethanol transportation to other countries) [35, 36]. These climate change impacts allow ethanol to be classified as an advanced biofuel according to RSF2 regulatory framework [31].

\section{Public policies}

There is a clear potential for $2 G$ ethanol to achieve a lower production cost compared to $1 G$ ethanol in the medium to long term, even considering several technological and market uncertainties. However, $2 \mathrm{G}$ process is at the beginning of its learning curve and expected improvements will depend on the diffusion and adoption of these new technologies. Therefore, additional mechanisms to encourage $R \& D$, as well as production and consumption of $2 \mathrm{G}$ ethanol in Brazil, can be proposed to accelerate the path along the learning curve.

By stimulating investment in the new $2 \mathrm{G}$ plants, there would be greater incentive for the development of the entire production chain, such as the establishment of local equipment and enzyme suppliers. Some incentives include premium prices, mandates, specific auctions, taxes exemption, and special credit lines for applied $R \& D$ focused on the main drivers of $2 G$ ethanol production costs. For instance, specific funding program for the development and use of energy cane could significantly reduce biomass cost and, integrated to $2 \mathrm{G}$ technology, would considerably increase ethanol production per crop area.

Therefore, if the suggested mechanisms are successfully implemented, they are likely to play an essential role to rapidly reach larger gains and, then, accelerate the diffusion of a new paradigm in the sugarcane industry, increasing the competitiveness of the sector [17].

\section{Conclusions}

Improvements in the biomass production system were projected considering the increase in agricultural yields, use of biomethane as diesel replacement, and introduction of energy cane beyond other expected improvements. Reduction in biomass costs reached about 55\% when comparing energy cane in the long term to conventional sugarcane in the short term, for example. 
The integration of $2 \mathrm{G}$ technology allowed an increase in ethanol production by 28,52 and $76 \%$ in the short, medium, and long terms, respectively. These increments are mainly associated with the advances on $2 \mathrm{G}$ technology and the processing of energy cane.

In terms of ethanol production costs, although $2 \mathrm{G}$ ethanol presents higher cost in the short term, the trend is that $2 \mathrm{G}$ ethanol cost will be competitive in the future. Therefore, public policies specifically designed to motivate the production and consumption of $2 \mathrm{G}$ ethanol in Brazil are essential to flatten the learning curve of $2 \mathrm{G}$ technology.

Environmental assessment results showed that both $1 \mathrm{G}$ and $2 \mathrm{G}$ ethanol are able to mitigate climate change impacts in comparison to gasoline, but higher benefits are achieved with $2 \mathrm{G}$ ethanol production. These results are aligned with the commitment of the Brazilian Government in its Intended Nationally Determined Contribution (INDC) to COP 21-Paris, 2015-to reduce GHG emission by increasing the share of sustainable biofuels in the Brazilian energy matrix [37].

\section{Additional file}

Additional file 1. Detailed information about biomass composition and production system as well as industrial process for different technology levels and timeframes.

\begin{abstract}
Abbreviations
1G: first generation; 1G2G: first and second generation; 2G: second generation; C5: 5-carbon molecules; C6: 6-carbon molecules; Capex: capital expenditure; CHP: cogeneration of heat and power; CTBE: Brazilian Bioethanol Science and Technology Laboratory; GHG: greenhouse gas; LCA: life cycle assessment; LCM: dry lignocellulosic material pretreated in the $2 \mathrm{G}$ process; LT: long term (2026-2030); MT: medium term (2021-2025); Mtoe: million metric tons of oil equivalent; R\&D: research and development; RFS: renewable Fuel Standard; ST: short term (2016-2020); TC: metric tons of cane; VSB: Virtual Sugarcane Biorefinery; WTI: West Texas intermediate.
\end{abstract}

\section{Authors' contributions}

TJ, VG, and MR carried out process simulations. MC and OC modeled agricultural phase and performed environmental assessment. CJ and MW calculated capital and operational costs. AM discussed alternatives for public policies. AB coordinated the study, including the definition of scenarios. TJ was a major contributor in writing the manuscript. All authors contributed to the writing of specific sections. All authors read and approved the final manuscript.

\section{Author details}

${ }^{1}$ Laboratório Nacional de Ciência e Tecnologia do Bioetanol (CTBE), Centro Nacional de Pesquisa em Energia e Materiais (CNPEM), Caixa Postal 6192, Campinas, SP CEP 13083-970, Brazil. ${ }^{2}$ Faculdade de Engenharia Química, Universidade Estadual de Campinas (UNICAMP), Campinas, SP, Brazil. ${ }^{3}$ Departamento de Biocombustíveis, Banco Nacional de Desenvolvimento Econômico e Social (BNDES), Rio de Janeiro, RJ, Brazil.

\section{Acknowledgements}

The authors gratefully acknowledge financial support received from FAPESP (Grant Nos: 2011/51902-9 and 2010/17139-3). The authors would like to thank the specialists and companies that contributed to the assumptions definition, with the support of BNDES and CGEE-MCTIC.

\section{Competing interests}

The authors declare they have no competing interests.

\section{Availability of data and materials}

The datasets during and/or analyzed during the current study are available from the corresponding author on reasonable request.

\section{Funding}

This study was funded by the São Paulo Research Foundation (Fapesp) and Ministry of Science, Technology, Innovation and Communications (MCTIC).

Received: 5 October 2016 Accepted: 2 February 2017

Published online: 14 March 2017

\section{References}

1. EPE_Energy Research Company. National energy balance 2015: 2014 base year. 2015. https://ben.epe.gov.br/downloads/Relatorio_Final_ BEN_2015.pdf. Accessed 20 Jan 2016.

2. Gallina ES, de Oliveira Cruz L, Matias F. Brazilian Public Policies and Sustainable Development that Influence the National Bioindustry. In: Leal Filho W, Pociovalisteanu DM, Al-Amin AQ, editors. Sustainable economic development. Basel: Springer International Publishing; 2017. p. 127-39.

3. Van den Wall Bake JD, Junginger M, Faaij A, Poot T, Walter A. Explaining the experience curve: cost reductions of Brazilian ethanol from sugarcane. Biomass Bioenerg. 2009;33(4):644-58.

4. Goldemberg J, Coelho ST, Nastari PM, Lucon O. Ethanol learning curvethe Brazilian experience. Biomass Bioenerg. 2004;26(3):301-4.

5. IEA Bioenergy. From 1st-to 2nd-generation biofuel technologies: an overview of current industry and RD\&D activities. 2008. https://www. iea.org/publications/freepublications/publication/2nd_Biofuel_Gen.pdf. Accessed 9 May 2016

6. Baeyens J, Kang Q, Appels L, Dewil R, Lv Y, Tan T. Challenges and opportunities in improving the production of bio-ethanol. Prog Energ Combust. 2015;47:60-88.

7. Zabed H, Sahu JN, Boyce AN, Faruq G. Fuel ethanol production from lignocellulosic biomass: an overview on feedstocks and technological approaches. Renew Sust Energy Rev. 2016;66:751-74.

8. Pereira SC, Maehara L, Machado CMM, Farinas CS. 2G ethanol from the whole sugarcane lignocellulosic biomass. Biotechnol Biofuels. 2015;8:44.

9. Dias MOS, Junqueira TL, Cavalett $O$, Cunha MP, Jesus CDF, Rossell CEV, Maciel Filho R, Bonomi A. Integrated versus stand-alone second-generation ethanol production from sugarcane bagasse and trash. Bioresour Technol. 2012;103(1):152-61.

10. Dias MOS, Junqueira TL, Cavalett O, Pavanello LG, Cunha MP, Jesus CDF, Maciel Filho R, Bonomi A. Biorefineries for the production of first and second-generation ethanol and electricity from sugarcane. Appl Energy. 2013;109:72-8

11. Junqueira $T L$, Cavalett $O$, Bonomi A. The virtual sugarcane biorefinery-a simulation tool to support public policies formulation in bioenergy. Ind Biotechnol. 2016;12(1):62-7.

12. Gomes JR. Raízen avança no etanol de 2a geração. 2016. In O Estado de S. Paulo. http://economia.estadao.com.br/noticias/geral,raizen-avanca-noetanol-de-2-geracao,10000089302. Accessed 16 Dec 2016.

13. Wang L, Quiceno R, Price C, Malpas R, Woods J. Economic and GHG emissions analyses for sugarcane ethanol in Brazil: looking forward. Renew Sust Energ Rev. 2014;40:571-82.

14. Peplow M. Cellulosic ethanol fights for life. Nature. 2014;507:152-3.

15. EPA-US. Environmental Protection Agency. Renewable Fuel Standard Program. 2016. http://www.epa.gov/renewable-fuel-standard-program. Accessed 20 Jan 2016.

16. BNDES-Brazilian Development Bank. BNDES and Finep signs R\$ 1 bn agreement to finance innovation in the sugar and ethanol sector. 2011. http://www.bndes.gov.br/SiteBNDES/bndes/bndes_en/Institucional/ Press/Noticias/2011/20110321_BNDES_ethanol.html. Accessed 20 Jan 2016.

17. Milanez AY, Nyko D, Valente MS, Sousa LC, Bonomi A, Jesus CDF, Watanabe MDB, Chagas MF, Rezende MCAF, Cavalett O, Junqueira TL, Gouveia VLR. De promessa a realidade: como o etanol celulósico 
pode revolucionar a indústria da cana-de-açúcar: uma avaliação do potencial competitivo e sugestões de política pública. BNDES Setorial. 2015:41:237-94

18. Chen X, Shekiro J, Pschorn T, Sabourin M, Tucker MP, Tao L. Techno-economic analysis of the deacetylation and disk refining process: characterizing the effect of refining energy and enzyme usage on minimum sugar selling price and minimum ethanol selling price. Biotechnol Biofuels. 2015;8:173

19. Mesa L, López N, Cara C, Castro E, González E, Mussatto SI. Technoeconomic evaluation of strategies based on two steps organosolv pretreatment and enzymatic hydrolysis of sugarcane bagasse for ethanol production. Renew Energ. 2016;86:270-9.

20. Joelsson E, Erdei B, Galbe M, Wallberg O. Techno-economic evaluation of integrated first-and second-generation ethanol production from grain and straw. Biotechnol Biofuels. 2016;9:1.

21. Macrelli S, Galbe M, Wallberg O. Effects of production and market factors on ethanol profitability for an integrated first and second generation ethanol plant using the whole sugarcane as feedstock. Biotechnol Biofuels. 2014;7:26

22. Silva CRU, Franco HCJ, Junqueira $T L$, van Oers $L$, van der Voet $E$, Seabra JEA. Long-term prospects for the environmental profile of advanced sugar cane ethanol. Environ Sci Technol. 2014:48:12394-402.

23. Jonker JGG, van der Hilst F, Junginger $H M$, Cavalett $\mathrm{O}$, Chagas MF, Faaij APC. Outlook for ethanol production costs in Brazil up to 2030, for different biomass crops and industrial technologies. Appl Energy. 2015;147:593-610.

24. Bonomi A, Cavalett O, Cunha MP, Lima MAP, editors. Virtual biorefineryan optimization strategy for renewable carbon valorization. 1st ed. Basel: Springer International Publishing; 2016.

25. Watanabe MDB, Pereira LG, Chagas MF, Cunha MP, Jesus CDF, Souza A, Rivera EC, Maciel Filho R, Cavalett O, Bonomi A. Sustainability assessment methodologies. In: Bonomi A, Cavalett O, Cunha MP, Lima MAP, editors. Virtual biorefinery - an optimization strategy for renewable carbon valorization. Basel: Springer International Publishing; 2016. p. 155-88.

26. CEPEA-Center for advanced studies on applied economics. 2014. http:// www.cepea.esalq.usp.br. Accessed 15 July 2014.

27. MME-Ministry of mines and energy. Energy auctions. 2014. http://www. mme.gov.br/programas/leiloes_de_energia/. Accessed 15 July 2014.
28. Cardoso TF, Chagas MF, Rivera EC, Cavalett O, Morais ER, Geraldo VC, Braunbeck $\mathrm{O}$, Cunha MP, Cortez LAB, Bonomi A. A vertical integration simplified model for straw recovery as feedstock in sugarcane biorefineries. Biomass Bioenerg. 2015;81:216-23.

29. Goedkoop MJ, Heijungs R, Huijbregts M, De Schryver A, Struijs J, Van Zelm R. ReCiPe 2008, a life cycle impact assessment method which comprises harmonised category indicators at the midpoint and the endpoint level; First edition (version 1.8). Report I: Characterisation; (updated May 2013). http://www.lcia-recipe.net. Accessed 16 Dec 2016.

30. IPCC-Intergovernmental Panel on Climate Change. Climate Change 2007: synthesis report. In: Pachauri RK and Reisinger A, editors. Contribution of Working Groups I, II and III to the Fourth Assessment Report of the Intergovernmental Panel on Climate Change [Core Writing Team. London: IPCC; 2007.

31. U.S. Department of Energy. Energy Independence and Security Act of 2007. Summary of Public Law 110-140. Washington, D.C.: US Government Printing Office; 2008.

32. AFDC-Alternative Fuels Data Center. Ethanol Feedstocks. 2016. http:// www.afdc.energy.gov/fuels/ethanol_feedstocks.html. Accessed 16 Dec 2016.

33. U.S. ElA-United States Energy Information Administration. Independent statistics and analysis. 2014. http://www.eia.gov/tools/faqs/faq $\mathrm{cfm} ? \mathrm{id}=228 \mathrm{t}=10$. Accessed 26 Nov 2014

34. Nasdaq. End of day commodity futures price quotes for crude oil WTI. 2015. http://www.nasdaq.com/markets/crude-oil.aspx. Accessed 12 Apr 2015.

35. Department for Transport, UK. Carbon and sustainability reporting within the renewable transport fuel obligation-requirements and guidance. Government Recommendation to the Office of the Renewable Fuels Agency. London: Department for Transport Great Minster House; 2008.

36. Environmental Protection Agency (EPA). Regulation of fuels and fuel additives: changes to renewable fuel standard program. Washington, DC: Federal Register; 2010.

37. UNFCCC. Intended nationally determined contributions. 2015. http:// www4.unfccc.int/submissions/INDC/. Accessed 10 July 2016.

\section{Submit your next manuscript to BioMed Central and we will help you at every step:}

- We accept pre-submission inquiries

- Our selector tool helps you to find the most relevant journal

- We provide round the clock customer support

- Convenient online submission

- Thorough peer review

- Inclusion in PubMed and all major indexing services

- Maximum visibility for your research

Submit your manuscript at www.biomedcentral.com/submit
() Biomed Central 